\title{
Effects that nutritional and saline gradients have on the growth of Passiflora mucronata Lam. and Canavalia rosea (Sw.) DC. found in the restinga of Brazil
}

\author{
Jehová Lourenço Junior ${ }^{1}$, Oberdan Zambom ${ }^{1}$, Magda Santos Rossi ${ }^{1}$ and Geraldo Rogério Faustini Cuzzuol ${ }^{1,2}$
}

Submitted: 30 July, 2012. Accepted: 24 December, 2012

\begin{abstract}
Salinity and fertility are the main factors cited in Within the restinga (coastal woodland) biome in Brazil, the positioning of Canavalia rosea and Passiflora mucronata occur, respectively, near the shore-in the creeping psammophyte formation (CPF) - and far from the shore - in the Palmae formation (PF). The hypothesis that such positioning is related to salinity and fertility was tested by applying a salt gradient (increasing solutions of $\mathrm{NaCl}$ ) and a nutritional gradient (different proportions of Hoagland solution). Neither species survived in solutions over $200 \mathrm{mM}$ of $\mathrm{NaCl}$. The shoots of $P$. mucronata showed negative growth (lower dry mass) in the first week of exposure to saline solutions. The roots of $C$. rosea showed great sensitivity to salinity, which resulted in greater growth reduction, with increasing plant age, in comparison with $P$. mucronata. C. rosea grew best in the nutrient-deficient solution, whereas $P$. mucronata responded best to the nutrient-rich solution, suggesting that $C$. rosea is better able to populate less fertile sites, such as the CPF, whereas P. mucronata is more suited to sites that are more fertile, such as the PF. Therefore, we can speculate that fertility is the only factor limiting the positioning of species in the restinga.
\end{abstract}

Key words: Coastal ecosystems, Fabaceae, fertility, nutrition, Passifloraceae, salinity, spatial distribution

\section{Introduction}

The biome known in Brazil as restinga (coastal woodland) is an ecosystem typical of the Brazilian Atlantic coast (Araujo 1992) and is found on soils originating from the accumulation of crystalline sediments and marine transgression dating from the Quaternary (Suguio \& Martin 1990). Restingas comprise various vegetative formations, with distinct physiognomies, structures and floristic compositions, which increase in complexity with increasing distance from the shoreline (Cogliatti-Carvalho et al. 2001; Cordeiro 2005).

One fairly typical restinga is located within Paulo César Vinha State Park, in the municipality of Guarapari, in the state of Espírito Santo, Brazil. Along the coastal edge of that restinga lies the creeping psammophyte formation (CPF), comprising stoloniferous plants such as Canavalia rosea (Sw.) DC. (Fabaceae), which has a high degree of importance in terms of vegetative cover along the coastline of Espírito Santo and has a pantropical distribution (Thomaz \& Monteiro 1993). The vegetation of the CPF has low diversity and is exposed to environmental stresses such as high radiation and the action of saline aerosols (Menezes
\& Araujo 2000). Heading inland, the CPF gives way to the Palmae formation $(\mathrm{PF})$, characterized by greater diversity in relation to the $\mathrm{CPF}$. The PF is dominated by the palm Allagoptera arenaria (Gomes) O. Ktze associated with, among other species, Passiflora mucronata Lam. (Passifloraceae), a liana of tropical distribution.

The distribution of plant species of the restinga has been attributed to the action of edaphoclimatic components, of which topography (Cordeiro 2005), salinity and soil fertility (Cogliatti-Carvalho et al. 2001, Lourenço Junior \& Cuzzuol 2009) are the most often discussed. The role that sand plays in the burial of seeds has also been associated with the distribution of plants in coastal environments (Pires et al. 2006).

According to Griffiths (2006), the diversity and structure of vegetative formations along the coastline are associated with different levels of resistance to saline aerosols, crucial in the establishment of ecotypes. Due to the proximity of the CPF to the coast, C. rosea is exposed to high levels of salinity, especially during high tide, which led Lourenço Junior \& Cuzzuol (2009) to postulate that this species is resistant to salinity. Such resistance would, hypothetically, be the principal factor for the positioning of this species in the CPF. In contrast, $P$. mucronata, preferentially occupies

\footnotetext{
${ }^{1}$ Universidade Federal do Espírito Santo, Departamento de Ciências Biológicas, Vitória, ES, Brazil

${ }^{2}$ Author for correspondence: gcuzzuol@gmail.com
} 
regions farther from the coastline, where saline aerosols have less impact. The fact that $C$. rosea occupies an area near the ocean, where halophytes such as Blutaparon portulacoides and Alternanthera maritima (Thomaz \& Monteiro 1993) also occur, suggests that $C$. rosea is also a halophyte, whereas $P$. mucronata could be classified as a glycophyte (Lourenço Junior \& Cuzzuol 2009).

In addition to salinity, other physical and chemical soil characteristics have been associated with the distribution of native species in coastal biomes (Menezes \& Araújo 2000; Emery et al. 2001; Cuzzuol \& Campos 2001; Lourenço Junior \& Cuzzuol 2009). Such characteristics can be considered important factors in the establishment of $C$. rosea and $P$. mucronata, as these species have different nutritional requirements. This deduction is underscored by edaphic analyses of the restinga of the Paulo César Vinha State Park, which have shown that soil fertility is greater in the PF than in the CPF (Lourenço Júnior \& Cuzzuol 2009).

Hypotheses regarding the establishment of plant species in coastal environments can be tested by analysis of plant growth, as suggested by Cuzzuol \& Campos (2001) and extensively applied in studies related to the interactions between plants and the environment (Lambers \& Poorter 1992; Lambers et al. 1998; Poorter \& Nagel 2000; Poorter et al. 2009). In general, halophytes can tolerate up to 600 $\mathrm{mM} \mathrm{NaCl}$ (Lu et al. 2003; Parida et al. 2003), compared with only $200 \mathrm{mM}$ for glycophytes (Marschner et al. 1996). However, in some species that are classified as halophytes, growth is hampered by exposure to $\mathrm{NaCl}$ solutions in excess of $300 \mathrm{mM}$ (Bell \& O'Leary 2003; Lu et al. 2003). Another difference between these two groups of plants is in terms of the specific leaf area (SLA). In general, halophytes feature increased SLA at high salinities, although no variation of this foliar parameter has been observed in glycophytes (Poorter et al. 2009). Some symptoms of nutritional and saline stress are quite similar. Such symptoms include a reduction in biomass and in the percentage of survival of the plants (Benlloch-González et al. 2005), as well as lower growth rates (Chen et al. 2003; Cuzzuol et al. 2005a), low foliar succulence, higher root/shoot ratio (R:SR, Garg \& Singla 2004; Cambraia 2005) and a reduction in photosynthetic activity (Lee et al. 2004; Cuzzuol et al. 2008).

Lourenço Júnior \& Cuzzuol (2009) performed physical and chemical analyses of the soils of the restinga of Paulo César Vinha State Park, the results of which suggested that soil characteristics influence the establishment of $C$. rosea in the $\mathrm{CPF}$ and of P. mucronata in the PF. According to those authors, an evaluation of the effects that the availability of mineral nutrients and salinity has on the growth of $C$. rosea and $P$. mucronata could produce relevant information on the dynamics of spatial distribution of these species in restinga environments. Therefore, the objective of the present study was to evaluate the responses of $C$. rosea and $P$. mucronata to a saline gradient and a mineral nutrient gradient. The results could further the understanding of the abiotic fac- tors involved in the positioning of plant species in coastal environments and open new possibilities for investigations into the dynamics of species distribution within formations of the restinga biome.

\section{Material and methods}

\section{Biological material and experimental design}

The study area is located in Paulo César Vinha State Park $\left(20^{\circ} 33^{\prime}-20^{\circ} 38^{\prime} \mathrm{S}\right.$ and $\left.40^{\circ} 23^{\prime}-40^{\circ} 26^{\prime} \mathrm{W}\right)$, within the municipality of Guarapari, in the state of Espírito Santo, Brazil. The species studied were Canavalia rosea (Sw.) DC. (Fabaceae), which is abundantly distributed in the CPF, and Passiflora mucronata Lam. (Passifloraceae), which occurs in the PF. The abundant production of seeds of $C$. rosea and P. mucronata contributed to the choice of these species for the present study.

The fruits were collected and the biological material was taken to the Plant Ecophysiology Laboratory of the Biological Sciences Department at the Federal University of Espírito Santo, located in the city of Vitória, in the state of Espírito Santo. In the case of P. mucronata, seeds were removed from the fruit, washed in running water and dried at room temperature for $24 \mathrm{~h}$ to remove the aril. In order to shorten the average germination time (estimated at 10-90 days for Passifloraceae species) and to produce homogeneous seedlings, seeds were immersed in a solution of ascorbic acid $\left(150 \mathrm{mg} \mathrm{L}^{-1}\right)$ at $10^{\circ} \mathrm{C}$ for $12 \mathrm{~h}$, which reduced the average germination time to less than 10 days, according to preliminary results. The seeds of $C$. rosea were removed from dried fruit and mechanically scarified (Lucas \& Arrigoni 1992). For germination, the seeds of the two species were set in plastic trays containing washed sand and placed on counters in a greenhouse under the following environmental conditions: average temperature of $27 \pm 2^{\circ} \mathrm{C}$; natural photoperiod of $11 \pm 1 \mathrm{~h}$; luminosity of $500 \pm 150 \mu \mathrm{mol}$ $\mathrm{m}^{2} \mathrm{~s}^{-1}$ of photosynthetically active radiation; and relative humidity of $70 \pm 20 \%$.

At 20-30 days after germination, healthy, homogeneous plants were transplanted into 3-L plastic pots containing sediment from the CPF of the restinga, selected because of its lower fertility (Lourenço Junior \& Cuzzuol 2009).

\section{Saline gradient}

At 14 days after transplantation, the plants were distributed into four lots, each plant receiving a single 450 -ml application of either 0 (control), 200, 400 or $600 \mathrm{mM} \mathrm{NaCl}$. This volume allowed for the collection of $10 \mathrm{ml}$ of the solution drained through the sediment for later analysis of electrical conductivity (EC) with a conductivity meter (SCHOTT Instruments handylab LF II; SI Analytics, Mainz, Germany). The EC of the solutions after draining was as follows: 3.76

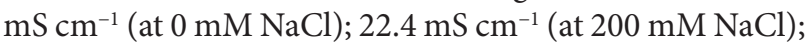


$37.62 \mathrm{mS} \mathrm{cm}^{-1}$ (at $400 \mathrm{mM} \mathrm{NaCl}$ ); and $53.94 \mathrm{mS} \mathrm{cm}^{-1}$ (at 600 $\mathrm{mM} \mathrm{NaCl}$ ). The pots were watered weekly with aliquots of distilled water and samples of drained water were collected for monitoring EC values. When necessary, aliquots of saline solutions were applied to maintain the initial value of EC. In order to avoiding dehydration of the plants, aliquots of distilled water were applied daily in small volumes without changing the saline concentration. This procedure was done with care to maintain the substrate damp but not saturated.

\section{Nutritional gradient}

We created an experimental nutritional gradient using Hoagland solution (Hoagland \& Arnon 1938), in the proportions $0.2 \times$ (deficient solution), $1 \times$ (original solution) and $2 \times$ (enriched solution), and the $\mathrm{pH}$ was adjusted to 5.5-6.0 (Cuzzuol et al. 2008). Volumes of $50 \mathrm{ml}$ of nutrient solutions were applied, weekly, interspersed with distilled water as needed, to prevent desiccation of the plants. Every month, the substrates were watered with distilled water at a volume above saturation to promote the leaching of salts, thus avoiding salinization as described by Cuzzuol et al. (2005a; b).

\section{Growth analysis}

The salinity experiment lasted 56 days, and the nutrition experiment lasted 90 days. For the salinity experiment, we measured shoot dry mass (ShDM) and root dry mass $(\mathrm{RDM})$ at $7,14,28$ and 56 days using seven plants for each experimental time; values were expressed in terms of the percentage increase in dry mass relative to that of the start time. This procedure showed the magnitude of increase or reduction of dry mass in relation to a particular growth factor and is indicated for native species characterized by greater variability compared to cultivated species (Poorter \& Nagel 2000). In addition to these measures, the total leaf area (TLA), RDM, stem dry mass (StDM) and leaf dry mass (LDM) at the starting and ending times of plants grown with 0 and $200 \mathrm{mM} \mathrm{NaCl}$ (where all the plants survived until the end of the experimental period) were recorded for the calculation of growth rates and ratios. At the higher concentrations of $\mathrm{NaCl}, 100 \%$ mortality occurred in the first weeks of treatment. Plants that lacked green color in the leaf blade were considered dead. Other measurements such as the maximum stem length (MSL) and the number of leaves (NL) at the ending time were also made. From these primary values, the R:SR, leaf mass ratio (LMR), SLA, leaf area ratio (LAR), net assimilation rate (NAR) and relative growth rate (RGR) were calculated for plants grown using 0 and $200 \mathrm{mM} \mathrm{NaCl}$ for a better understanding of the effects of salinity on growth measures. The same growth measurements used in the salinity experiment were also analyzed for seven plants at 0 and 90 days in the various treatments of the mineral nutrition experiment. In this case, as there was no mortality of plants under the treatments applied, all measurements were performed for all treatments. The measurements taken at the starting time are not presented, as they were used as a reference for the calculation of the percentage increase in dry mass, growth rates and ratios at 90 days of treatment. In both experiments, the dry mass was determined after placing the plant material in an oven at $60^{\circ} \mathrm{C}$ with forced air circulation until achieving constant dry mass at all experimental times. Leaf area was calculated using an image reader (Area Meter 3100C; LI-COR, Lincoln, NE, USA). From these primary measurements, growth rates and ratios were calculated using the methodology of Evans (1972) and Hunt (1982). As such, the LAR was determined by dividing leaf area by total dry mass (TDM), the SLA by the ratio between the total leaf area and leaf dry mass, the LMR by the quotient of leaf dry mass divided by total dry mass, the NAR by the equation $\left[\left(\ln A_{2}-\ln A_{1} / A_{2}-A_{1}\right)\right] \times$ $\left[\left(\mathrm{M}_{2}-\mathrm{M}_{1}\right) /\left(\mathrm{t}_{2}-\mathrm{t}_{1}\right)\right]$, and the RGR by the equation $\left[\left(\ln \mathrm{M}_{2}\right.\right.$ $\left.\left.-\ln \mathrm{M}_{1}\right) / \mathrm{t}_{2}-\mathrm{t}_{1}\right]$ and also deduced by the product of its components $(\mathrm{RGR}=\mathrm{SLA} \times \mathrm{LMR} \times \mathrm{NAR})$. The percentage of increase in dry mass (\% increase in DM) was calculated by the equation $\left[\left(M_{2}-M_{1}\right) / M_{1} \times 100\right]$, where $M_{2}$ is the final dry mass, $M_{1}$ is the initial dry mass, $A_{2}$ is the final leaf area, $A_{1}$ is the initial leaf area, and $t_{2}-t_{1}$ is the time interval between the two collections.

\section{Experimental design and statistical analysis}

The experiment followed a completely randomized design, using seven plants per treatment for the two experiments. The analyses of the salinity experiment were performed at 7, 14, 28 and 56 days, and the nutritional gradient experiment, at 0 and 90 days. The two experiments followed a factorial model with the salinity experiment using a $4 \times 4$ schema for a total of 112 samples while the nutritional gradient used a $3 \times 2$ schema totaling 42 samples. The data were subjected to ANOVA and, when necessary, the averages were compared using Duncan's test $(\mathrm{p} \leq 0.05)$ using the software ASSISTAT, version 7.4 (Silva \& Azevedo 2007). The data had a normal distribution. As for the analysis of percentage increase in dry mass, the statistic was applied only when the values were positive.

\section{Results}

The symptoms of saline stress indicated by the negative growth values of TDM, ShDM and RDM appeared more immediately and acutely in P. mucronata (Fig. 1). However, C. rosea showed greater sensitivity to salinity at more advanced periods of plant growth, especially at 56 days when the increase in TDM, ShDM and RDM was significantly lower with the $200 \mathrm{mM} \mathrm{NaCl}$ solution.

Concentrations above $200 \mathrm{mM} \mathrm{NaCl}$ were lethal to both species, with $P$. mucronata more sensitive to salinity at the beginning of growth, showing early symptoms of toxicity 

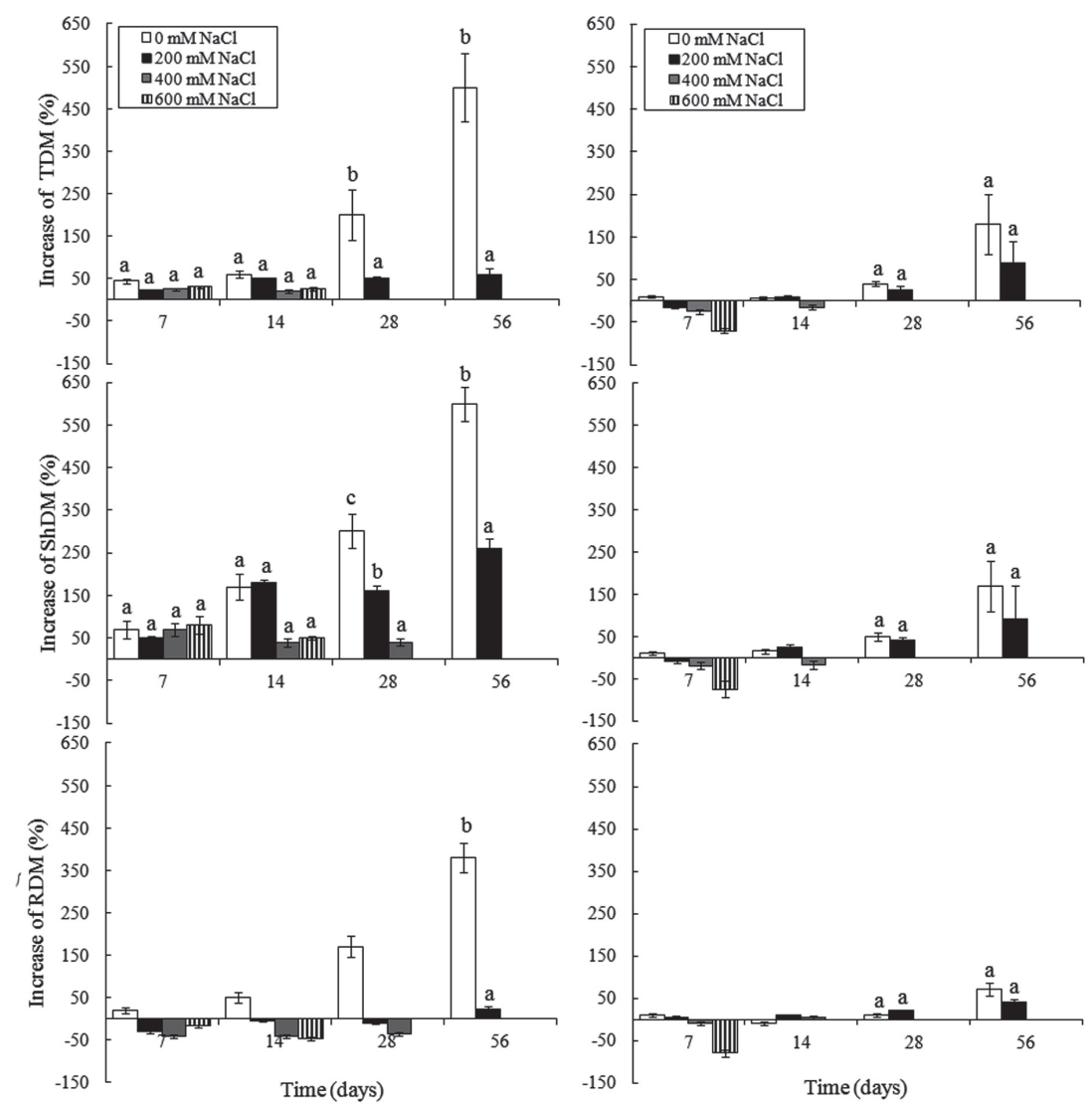

Figure 1. Effect of the salinity gradient on the increase in total dry mass (TDM), shoot dry mass (ShDM) and root dry mass (RDM) of $P$. mucronata and $C$. rosea at 7, 14, 28 and 56 days of cultivation. The bars indicate the standard deviation and the letters differ significantly according to the Duncan's test between species within the same $\mathrm{NaCl}$ concentration and experimental period $(\mathrm{p} \leq 0.05$ and $\mathrm{n}=7)$.

followed by $100 \%$ mortality at 14 days in $600 \mathrm{mM} \mathrm{NaCl}$ based on the absence of increased values for dry mass (Fig. 1). This effect occurred later in C. rosea, specifically from day 28 onwards. No plant of $P$. mucronata resisted the concentration of $400 \mathrm{mM} \mathrm{NaCl}$ at 28 days, for C. rosea, $100 \%$ mortality occurred at 56 days. Plants that did not survive to the high concentrations of $\mathrm{NaCl}$ were discarded.

The highest concentrations of $\mathrm{NaCl}$ more greatly reduced the increase in dry biomass (Fig. 1) and the other growth measurements (Tab. 1) in C. rosea than in P. mucronata. The percentage of increase in TDM, ShDM and RDM in $P$. mucronata declined to negative values in the solutions containing $\mathrm{NaCl}$ showing reduction in the dry mass increment relative to the control. This result was more pronounced with more concentrated solutions of $\mathrm{NaCl}$. At 14 days, there was a return to increased values of TDM, ShDM and RDM at $200 \mathrm{mM}$ of $\mathrm{NaCl}$, with these parameters reaching positive values. However, at $400 \mathrm{mM} \mathrm{NaCl}$ the values remained negative but showed signs of recovery with dry mass decreasing by a smaller value. In $C$. rosea, the reduction in dry mass was only observed at 7 and 14 days in the change of RDM in all treatments containing $\mathrm{NaCl}$ (Fig. 1). The recovery of growth in RDM only happened with $200 \mathrm{mM}$ when it attained a positive value at 56 days.

Unlike P. mucronata, the root system of C. rosea proved to be more sensitive to the more concentrated solutions of $\mathrm{NaCl}$, showing greater negative values in saline solutions at 24 and 28 days (Fig. 1). Analyzing the performance of plants with 0 and $200 \mathrm{mM} \mathrm{NaCl}$ the lack of a difference can be noted between these solutions in terms of growth of TDM, ShDM and RDM at 28 and 56 days in P. mucronata, whereas C. rosea had greater values at $0 \mathrm{mM}$ and with a significant difference in relation to the $200 \mathrm{mM} \mathrm{NaCl}$ solution (Fig. 1). In this regard, $P$. mucronata had an average value of $75 \%$ growth in ShDM at 56 days with $200 \mathrm{mM} \mathrm{NaCl}$ while this value was of $250 \%$ in C. rosea for the same time and salt concentration.

The effects of 0 and $200 \mathrm{mM} \mathrm{NaCl}$ solutions on the growth of biomass of the two species at 56 days were also observed in other growth variables at the same sampling time (Tab. 1). Salinity affected all growth measures of the two species, but the effects were more pronounced in $C$. rosea. However, in terms of SLA, salinity did result in any difference from the control in P. mucronata. However, the 
Table 1. Average values of the growth measurements of plants treated with solutions of 0 and $200 \mathrm{mM} \mathrm{NaCl}$ at 56 days of cultivation.

\begin{tabular}{|c|c|c|c|c|c|c|c|c|c|c|c|c|c|c|c|}
\hline \multirow{2}{*}{ Species } & $\mathrm{NaCl}$ & MSL & NL & TLA & RDM & StDM & LDM & ShDM & TDM & R:SR & LMR & SLA & LAR & NAR & RGR \\
\hline & $(\mathrm{mM})$ & $(\mathrm{m})$ & $(\mathbf{n})$ & $\left(\mathrm{cm}^{2}\right)$ & \multicolumn{6}{|c|}{ (g DM) } & $\left(\mathrm{g} \mathrm{g}^{-1}\right)$ & $\left(\mathrm{cm}^{2} \mathrm{~g}^{-1}\right)$ & $\left(\mathrm{cm}^{2} \mathrm{~g}^{-1}\right)$ & $\left(\mathrm{g} \mathrm{cm}^{-2}\right.$ day $\left.^{-1}\right)$ & $\left(\mathrm{mg} \mathrm{g}^{-1}\right.$ day $\left.^{-1}\right)$ \\
\hline \multirow{2}{*}{ C. rosea } & 0 & $0.2 \mathrm{~b}$ & $05 \mathrm{~b}$ & $179 b$ & $1.1 \mathrm{~b}$ & $0.5 b$ & $1.8 \mathrm{~b}$ & $2.3 \mathrm{~b}$ & $3.4 \mathrm{~b}$ & $0.5 \mathrm{~b}$ & $0.4 \mathrm{a}$ & $177 \mathrm{a}$ & $76 a$ & $0.479 b$ & $0.034 \mathrm{~b}$ \\
\hline & 200 & $0.1 \mathrm{a}$ & $03 a$ & $115 a$ & $0.3 \mathrm{a}$ & $0.3 \mathrm{a}$ & $0.8 \mathrm{a}$ & $1.1 \mathrm{a}$ & $1.4 \mathrm{a}$ & $0.3 \mathrm{a}$ & $0.5 \mathrm{a}$ & $189 \mathrm{~b}$ & $88 \mathrm{~b}$ & $0.215 a$ & $0.020 \mathrm{a}$ \\
\hline \multirow{2}{*}{ P. mucronata } & 0 & $0.4 \mathrm{~b}$ & $13 \mathrm{~b}$ & $102 \mathrm{~b}$ & $0.3 \mathrm{~b}$ & $0.3 \mathrm{~b}$ & $0.4 \mathrm{~b}$ & $0.7 \mathrm{~b}$ & $1.0 \mathrm{~b}$ & $0.4 \mathrm{a}$ & $0.4 \mathrm{a}$ & $227 \mathrm{a}$ & $84 a$ & $0.253 b$ & $0.023 b$ \\
\hline & 200 & $0.3 \mathrm{a}$ & $11 \mathrm{a}$ & 090a & $0.2 \mathrm{a}$ & $0.2 \mathrm{a}$ & $0.3 \mathrm{a}$ & $0.5 \mathrm{a}$ & $0.7 \mathrm{a}$ & $0.4 \mathrm{a}$ & $0.4 \mathrm{a}$ & $250 \mathrm{a}$ & $97 \mathrm{~b}$ & $0.156 a$ & $0.015 a$ \\
\hline
\end{tabular}

MSL - maximum stem length; NL - number of leaves; TLA - total leaf area; RDM - root dry mass; StDM - stem dry mass; LDM - leaf dry mass (blade); ShDM shoot dry mass; TDM - total dry mass; R:SR - root/shoot ratio; LMR - leaf mass ratio; SLA - specific leaf area; LAR - leaf area ratio; NAR -net assimilation rate; RGR - relative growth rate. Distinct letters within the same column differ significantly according to the Duncan's test ( $\mathrm{p} \leq 0.05$ and $\mathrm{n}=7)$ among the treatments with the same species.

LAR of both species was higher at $200 \mathrm{mM} \mathrm{NaCl}$ with the greatest difference in $C$. rosea. The damage that salt caused in the leaf measurements and dry weight of the two species was reflected in the smaller values for NAR and RGR, with these reductions more pronounced in C. rosea (Tab. 1).

As with salinity, the two species were also affected in terms of dry mass and other growth measures by the nutritional gradient (Tab. 2 and Fig. 2). In general, plants of $C$. rosea showed progressively reduced growth of TDM, ShDM and RDM with increased nutrient supply (Fig. 2). Plants of P. mucronata showed the opposite results. The increase in dry mass production for both the shoot and root systems was linear with the nutrient supply (Tab. 2). Likewise, similar results were observed with the other growth measures.

In general, the RDM, TDM, R:SR and SLA in C. rosea were greater in the nutrient-poor solution and these results were reflected in higher values for NAR and RGR with this solution. However, the MSL, StDM and ShDM of C. rosea were not influenced by the nutritional treatments. The values of the NL and the LDM did not reveal a clearly defined pattern in relation to the availability of nutrients, showing a tendency to greater values in deficient and enriched solutions. In these same solutions greater values for SLA and LAR were found (Tab. 2).

Plants of P. mucronata invested in MSL, NL and TLA in original and enriched Hoagland solutions, especially in the latter (Tab. 2). The increase in dry mass was also greater in these solutions as can be seen by the greater values of $\mathrm{RDM}$, LDM, StDM, ShDM and TDM. These results were reflected in the greater NAR and RGR of plants given the original and enriched solutions. However, the R:SR was greater in the deficient and original solutions. Nutrient availability did not influence the SLA and LAR values.

\section{Discussion}

The process of plant establishment, which includes germination, growth and survival, is very susceptible to damage caused by salinity and such effects tend to intensify with the age of the plants (Soares et al., 2002) as observed in P. mucronata and C. rosea in the present study.
In this regard, the shoots as well as the roots of $P . m u$ cronata showed greater sensitivity to salinity damage in the initial growth phase, while in C. rosea, such effects appeared later in the shoot yet were already striking in the roots in the first week. Comparing the two species, C. rosea showed greater sensitivity to salinity at 56 days with $200 \mathrm{mM} \mathrm{NaCl}$, with the most intense effects revealed in the lower values for dry mass increase, the reduction in growth of vegetative organs (MSL, TLA and dry mass of vegetative organs) and in NAR and RGR. These results can be attributed to the greater damage caused by $\mathrm{NaCl}$ in the photosynthetic activity of C. rosea, indicated by the greater reduction of NAR, as has already been found in plants of coastal environments under greater influence of salinity (Parida et al. 2003). As one of the morphological adjustments to higher salinity, the two species have invested in greater LAR to enlarge the photosynthetic leaf area in order to meet the greater demand for energy characteristic of plants that are under some kind of stress (Lambers \& Poorter 1992). In fact, the plants with $200 \mathrm{mM} \mathrm{NaCl}$ ended up using a greater leaf area to produce $1 \mathrm{~g}$ of dry matter, which shows that the level of salt used, to some degree, reduced the photosynthetic efficiency.

In part, this initial resistance of C. rosea to salinity may be related to its energy reserves. Considering that the vigor of the plants depends on the size of the seed and the content of its reserves (Melo et al. 2004), the larger NAR and RGR of $C$. rosea in relation to p. mucronata with the 0 and 200 $\mathrm{mM} \mathrm{NaCl}$ solutions can be explained by the greater size of its seeds rich in cell wall polysaccharide reserves of the xyloglucan type that can represent $40 \%$ of the dry mass of its seeds (Clippel et al. 2008). Additionally, the greater NAR and RGR of C. rosea may be associated with its taxonomic group being characterized by the presence of nitrogen-fixing nodules and rapid growth (Marschner 1999). All of these peculiarities associated with the stoloniferous growth habit and presence of coriaceous and succulent leaves of halophytic plants (Thomaz \& Monteiro 1993) may have contributed to the late effects of salinity in C. rosea. Another fact which supports the possibility of this species being a halophyte, even with the more intense effects of salinity at 56 days in relation to $P$. mucronata, is that plants resistant to salinity tend to increase the SLA of their succulent leaves 

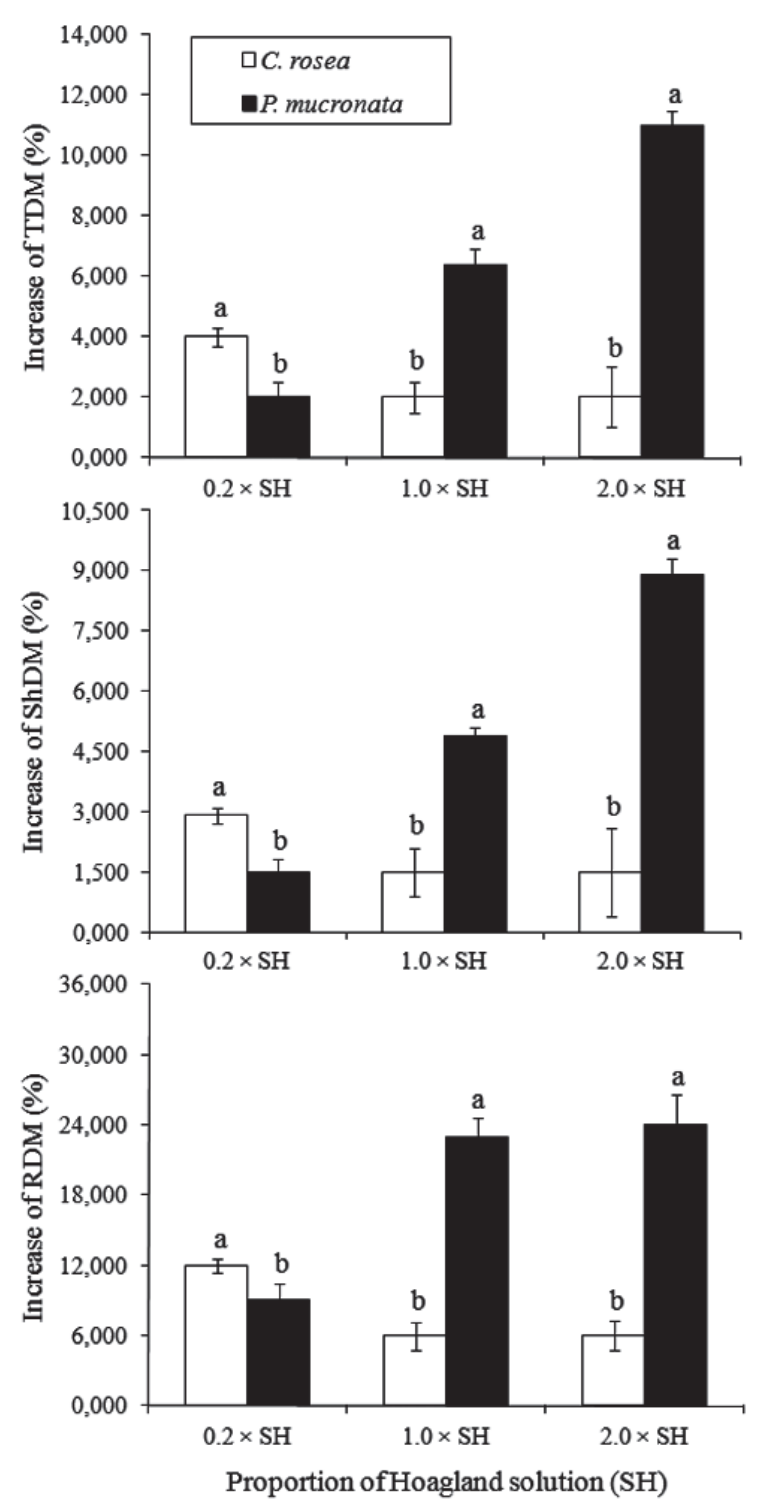

Figure 2. Effect of the nutritional gradient based on the proportion of the original Hoagland solution (HS) on the increase in total dry mass (TDM), shoot dry mass (ShDM) and root dry mass (RDM) of P. mucronata and C. rosea at 90 days of cultivation. The bars indicate the standard deviation and the letters differ significantly according to the Duncan's test between species within the same ionic strength and type of vegetative organ $(\mathrm{p} \leq 0.05$ and $n=7)$. with high concentrations of salts (Poorter et al. 2009) as was found in C. rosea at 56 days with $200 \mathrm{mM} \mathrm{NaCl}$. These reactions caused by the accumulation of salts constitute one of the components of the resistance of halophytes to salt stress (Flowers et al. 1977). Whereas in glycophytes, SLA is less influenced by salinity (Poorter et al. 2009) as was observed in P. mucronata. Therefore, SLA is considered a strong indicator of the level of resistance of plants to salinity and may be useful to classify species as halophytic of glycophytic (Poorter et al. 2009). Based on this information one can deduce that $C$. rosea is indeed a halophyte and $P$. mucronata, a glycophyte.

These interspecific differences in SLA between the two species appears to be related to the physical and chemical properties of the sediment in the restinga that have favored the dominance of $C$. rosea in the CPF, which is characterized by a higher soil sodium content in relation to the $\mathrm{PF}$, where of course, $P$. mucronata occurs (Lourenço Júnior \& Cuzzuol 2009). Another strong indication of the greater capacity of C. rosea to populate areas with elevated soil sodium content is the greater increase in ShDM of this species in relation to P. mucronata at 56 days of cultivation with $200 \mathrm{mM} \mathrm{NaCl}$.

The chronological specificity of sensitivity between the two species in relation to salinity could be related to interspecific differences in the speed of absorption and accumulation of $\mathrm{Na}^{+}$and $\mathrm{Cl}^{-}$( Marschner et al. 1996, Marschner 1999). Certainly, the two species must have specific mechanisms for the selection of these ions. The possibility of greater accumulation of ions in $P$. mucronata is sustained by the immediate damage with the greater concentrations of $\mathrm{NaCl}$ in the negative values of the ShDM added in the first week of exposure to the saline solutions. Whereas in C. rosea, the ions may have stimulated the synthesis of osmotically active solutes and in the osmoprotection imposed for up to 14 days by saline solutions as verified in Vigna unguiculata (Fabaceae) exposed to high salinity (Costa et al. 2003). This hypothetical osmotic and osmoprotective adjustment could explain the maintenance of the vigor of the leaves and stems of C. rosea as indicated by the increase in ShDM with more concentrated solutions of $\mathrm{NaCl}$ at 14 and 28 days. However, this fact cannot be verified as it was not evaluated in this work.

Table 2. Average values of the growth measurements of plants treated in a nutrient gradient based on the original proportion of Hoagland solution (HS), at 90 days of cultivation.

\begin{tabular}{|c|c|c|c|c|c|c|c|c|c|c|c|c|c|c|c|}
\hline \multirow{2}{*}{ Species } & $\mathrm{NaCl}$ & MSL & NL & TLA & RDM & StDM & LDM & ShDM & TDM & R:SR & LMR & SLA & LAR & NAR & RGR \\
\hline & $(\mathrm{mM})$ & (m) & (n) & $\left(\mathrm{cm}^{2}\right)$ & \multicolumn{6}{|c|}{ (g MS) } & $\left(\mathrm{g} \mathrm{g}^{-1}\right)$ & $\left(\mathrm{cm}^{2} \mathrm{~g}^{-1}\right)$ & $\left(\mathrm{cm}^{2} \mathrm{~g}^{-1}\right)$ & $\left(\mathrm{g} \mathrm{cm}^{-2}\right.$ day $\left.^{-1}\right)$ & $\left(\mathrm{mg} \mathrm{g}^{-1}\right.$ day $\left.^{-1}\right)$ \\
\hline \multirow{2}{*}{ C. rosea } & 0 & $0.2 \mathrm{~b}$ & $05 \mathrm{~b}$ & $179 \mathrm{~b}$ & $1.1 \mathrm{~b}$ & $0.5 \mathrm{~b}$ & $1.8 \mathrm{~b}$ & $2.3 \mathrm{~b}$ & $3.4 \mathrm{~b}$ & $0.5 \mathrm{~b}$ & $0.4 \mathrm{a}$ & $177 \mathrm{a}$ & $76 a$ & $0.479 \mathrm{~b}$ & $0.034 \mathrm{~b}$ \\
\hline & 200 & $0.1 \mathrm{a}$ & $03 a$ & $115 a$ & $0.3 \mathrm{a}$ & $0.3 \mathrm{a}$ & $0.8 \mathrm{a}$ & $1.1 \mathrm{a}$ & $1.4 \mathrm{a}$ & $0.3 \mathrm{a}$ & $0.5 \mathrm{a}$ & $189 \mathrm{~b}$ & $88 \mathrm{~b}$ & $0.215 \mathrm{a}$ & $0.020 \mathrm{a}$ \\
\hline \multirow{2}{*}{ P. mucronata } & 0 & $0.4 \mathrm{~b}$ & $13 \mathrm{~b}$ & $102 \mathrm{~b}$ & $0.3 \mathrm{~b}$ & $0.3 \mathrm{~b}$ & $0.4 \mathrm{~b}$ & $0.7 \mathrm{~b}$ & $1.0 \mathrm{~b}$ & $0.4 \mathrm{a}$ & $0.4 \mathrm{a}$ & $227 a$ & $84 a$ & $0.253 \mathrm{~b}$ & $0.023 b$ \\
\hline & 200 & $0.3 \mathrm{a}$ & $11 \mathrm{a}$ & 090a & $0.2 \mathrm{a}$ & $0.2 \mathrm{a}$ & $0.3 \mathrm{a}$ & $0.5 \mathrm{a}$ & $0.7 \mathrm{a}$ & $0.4 \mathrm{a}$ & $0.4 \mathrm{a}$ & $250 \mathrm{a}$ & $97 \mathrm{~b}$ & $0.156 a$ & $0.015 \mathrm{a}$ \\
\hline
\end{tabular}

MSL - maximum stem length; NL - number of leaves; TLA - total leaf area; RDM - root dry mass; StDM - stem dry mass; LDM - leaf dry mass (blade); ShDM - shoot dry mass; TDM - total dry mass; R:SR - root/shoot ratio; LMR - leaf mass ratio; SLA - specific leaf area; LAR - leaf area ratio; NAR -net assimilation rate; RGR - relative growth rate. Distinct letters differ significantly according to the Duncan's test $(\mathrm{p} \leq 0.05$ and $n=7)$ among the treatments with the same species. 
Although the greater investment in the root system has been interpreted as a striking response in plants that are exposed to some kind of stress (Garg \& Singla 2004; Cambraia 2005) plants of C. rosea at 56 days with $200 \mathrm{mM}$ $\mathrm{NaCl}$ invested less in the root system as indicated by the reduction in the R:SR, relative to the control. This damage can be related to physiological and morphological characteristics specific to the taxonomic group to which this species belongs. While it is considered a species of nitrogen-fixing Fabaceae, its nodules are very sensitive to the presence of salt (Garg \& Singla 2004; Nóbrega et al. 2004). In fact, the number of nodules of $C$. rosea was lower in the saline solution. This number came to represent a $20 \%$ reduction relative to the control (data not presented). Possibly, this damage has affected the nitrogen fixation which could have limited plant growth as has previously been observed in legumes under greater influence of salinity (Rao et al., 2002; Garg \& Singla 2004).

The death of the plants of the two species in solutions above $200 \mathrm{mM}$ could lead to the assertion that neither species are tolerant to salinity. However, some halophytic species occurring along the coastline, such as Sueda salsa and Sporobulos virginicus, have shown better performance at concentrations of less than $300 \mathrm{mM} \mathrm{NaCl}$ (Bell \& O'Leary 2003; Lu et al. 2003). Therefore, to better define which of the species is halophytic and which glycophytic it would be necessary to take into consideration not only the variations of SLA as discussed earlier, but also the responses of C. rosea and P. mucronata in a gradient from 0 to $200 \mathrm{mM} \mathrm{NaCl}$. Within this limit, it would be possible to determine the maximum resistance of each species to $\mathrm{NaCl}$ including other analyses such as the concentration of primary metabolites and water potential, which are commonly used in studies involving saline stress.

Information about the response of native species in relation to salinity are still quite scarce, especially with species from the restinga biome. In any case, under field conditions with the action of tides, plants of $C$. rosea do not support the salinity of the sea, dying days after contact with seawater (in loco observations). This response confirms the statement of Pereira (1990) that the CPF is under the constant influence of wave action at the portion closest to the sea, and may disappear as a result of high tide.

However, salinity does not seem to be the only environmental variable associated with the distribution of $C$. rosea and $P$. mucronata in the restinga of Paulo César Vinha State Park. Other factors such as the nutritional gradient of the sediment have been suggested in the distribution of plant species in coastal environments (Menezes \& Araújo 2000; Emery et al. 2001; Cuzzuol \& Campos 2001). In the restinga biome, the distribution of plant species has been attributed to increasing fertility in the sediment with increasing distances from the shoreline, as C. rosea is restricted to the less fertile sediment of the $\mathrm{CPF}$ and $P$. mucronata to the more fertile sediment of the PF (Lourenço Júnior \&
Cuzzuol 2009). Such a hypothesis can be confirmed by the exponential growth of $P$. mucronata and inhibitory growth of C. rosea with the increasing supply of nutrients in this study.

Evaluating the differences in dry mass increase among the nutrient-deficient and -enriched solutions, it is worth noting the greater capacity of $P$. mucronata compared to $C$. rosea to respond to the greater range of mineral nutrient availability. While $P$. mucronata showed a difference of up to a $500 \%$ increase in TDM and ShDM with the deficient solution compared the enriched one, C. rosea showed a $100 \%$ reduction of TDM, ShDM and RDM under the same comparison. These results demonstrate the greater capacity of genotypic adaptation of $P$. mucronata in relation to $C$. rosea to respond to an increased range of nutrient concentrations. The lesser plasticity of C. rosea, indicated by the lower variation in dry mass increase and other growth measurements in the nutritional gradient, and its better performance under nutritional deficiency suggest that fertility is a limiting factor in the distribution of this species of Fabaceae in the CPF. The greater growth of $P$. mucronata in response to increased nutrient availability, especially in terms of the significant increase in root and shoot dry mass, MSL and TLA with the enriched solution, must have contributed to its establishment in the PF. In fact, the physical and chemical properties of the sediment of the $\mathrm{PF}$ were considered more conducive to the development of $P$. mucronata in that locality than in the CPF (Lourenço Júnior \& Cuzzuol 2009).

One of the aspects that demonstrates the harmful effect of the greater supply of nutrients on the growth of C. rosea is the marked reduction of the R:SR. This result indicates that the root system of $C$. rosea has a higher capacity to develop in less fertile sites, typical of coastal environments where species like Jacquinia pungens also grow, whose roots were affected by an increased availability of nutrients (Rincon \& Huante 1994). Therefore, C. rosea has a characteristic of species well adapted to oligotrophic environments, especially as it is a species of Fabaceae with nitrogen-fixing nodules. According to Marschner et al. (1996), the nitrogen-fixing microorganisms stimulate better root development under nutritional restriction. This condition results in a greater demand for photosynthates by carbon-sink organs and, therefore, greater root growth as well as greater photosynthetic efficiency (Lambers \& Poorter 1992), as indicated by the larger NAR and RGR values and reflected by the smaller LAR of C. rosea in the deficient solution. In fact, the higher growth rates in the nutrient-deficient solution denote that this species and other legumes are able to express greater photosynthetic activity in low fertility environments (Marschner et al. 1996).

The better performance of $C$. rosea in the deficient solution can also be confirmed by the lesser value of SLA typical of plants from coastal environments such as $C$. rosea, which develops near the ocean where fertility is low (Lourenço Junior \& Cuzzuol 2009). The smaller RGR value of C. rosea 
cultivated in the enriched solution suggests, once again, the smaller capacity of this species to dominate fertile sites, which may have restricted its distribution to the CPF. However, the greater RGR values of $P$. mucronata in the original and enriched solutions confirm its ability to thrive in different formations (in loco observations) in the restinga, such as the PF. The PF is characterized by the greater fertility of its sediments (Lourenço Junior \& Cuzzuol 2009), suggesting that $P$. mucronata in more efficient in the absorption and use of mineral nutrients.

Levine et al. (1998) related greater efficiency in the use of nutrients with competitive interactions of species from coastal environments. Under nutritional limitation, competitive dominance would result in efficiency for the competition for nutrients, which could determine the distribution of the species along the increasing fertility gradient from the beach toward the mainland. Based on this complex plant-environment interaction, the existence of a nutrient-dependent competitive hierarchy has been suggested among plants in oligotrophic environments. According to Emery et al. (2001), this hierarchy would be under the control of the competition capacity of the root system. With greater sediment fertility, the shoot would be more competitive. On the basis of these reports and on the better growth of the shoot of P. mucronata (increased ShDM and growth rates) in original and enriched solutions, it can be affirmed that this species of Passifloraceae is better able to compete for sites of higher fertility than $C$. rosea.

The interspecific differences observed in the present study in relation to the supply of nutrients can be related to the process of nitrogen fixation. In fertile soils, the association with nitrogen-fixing bacteria would become somewhat disadvantageous to the host plant, by affecting the association with the rhizobia (Weng-Ming et al. 2000) as noted, indirectly, in C. rosea from the observation of fewer nodules present (data not presented) in enriched solution. In addition to fertility, another factor related to the distribution of the species is luminosity (Björkman 1981). According to Fitter (1997), leguminous plants that inhabit oligotrophic environments are highly dependent on the high intensity of solar radiation which may also have contributed to the placement of C. rosea in the CPF, where there is less effect of shading among the species (Thomaz \& Monteiro 1993).

The occurrence of leguminous crops in places of low fertility is an important aspect of ecological succession (Fitter 1997). This dynamic may have contributed to the placement of $C$. rosea in the CPF, which is characterized by low fertility and increased influence of salinity, whereas $P$. mucronata is restricted to the PF and other localities of greater fertility and under lesser influence of saline aerosols (Lourenço Junior \& Cuzzuol 2009). Considering that the two species were able to adjust better to the nutritional gradient than to the saline one, it is possible to speculate that fertility is the limiting factor in the positioning of species within the restinga biome. However, the study of environmental factors in isolation is not desirable from the ecological point- -of-view. Studies involving the interaction of salinity and fertility associated with other abiotic factors can provide important information for understanding the dynamics of coastal vegetation and of the determining factors for the positioning of plant species at restinga formations.

\section{Acknowledgements}

To Petrobras for granting a master's scholarship to the first author.

\section{References}

Araujo, D.S.D. 1992. Vegetation types of sandy coastal plains of tropical Brazil: a first approximation. Pp.337-347: In: Seeliger, U. (Ed.). Coastal plant communities of Latin America. San Diego, Academic Press.

Bell, H.L. \& O'Leary, J.W. 2003. Effects of salinity on growth and cation accumulation of Sporobolus virginicus (Poaceae). American Journal of Botany 90(10): 1416-1424.

Benlloch-Gonzáles, M.; Fournier, J.M.; Ramos, J. \& Benlloch, M. 2005. Strategies underlying salt tolerance in halophytes are present in Cinara cardunculus. Plant Science 168: 653-659.

Björkman, O. 1981. Responses to different quantum flux densities. Pp.57108. In: Lange, O.L.; Nobel, P.S.; Osmond, C.B.; Ziegler, H. (Ed.). Physiological Plant Ecology. (Encyclopedia of Plant Physiology. New Series, 12A). Berlin, Springer-Verlag.

Cambraia, J. 2005. Aspectos bioquímicos, celulares e fisiológicos dos estresses nutricionais em plantas. In: R.M.C. Nogueira; E.L. Araújo; L.G. Willadino \& U.M.T. Cavalcante (Orgs.). Estresses Ambientais: Danos e Benefícios em Planta. Pernambuco, Imprensa Universitária da UFRPE,

Chen, S.; Li, J.; Wang, S.; Fritz, E.; Hüttermann, A. \& Altman, A. 2003. Effects of $\mathrm{NaCl}$ on shoot growth, transpiration, ion compartmentation, and transport in regenerated plants of Populus euphratica and Populus tomentosa. Canadian Journal of Forest Research 33(6): 967-975.

Clippel, J.K.; Carmo, H.N.C.; Nascimento, L.C.Z. \& Cuzzuol, G.R.F. 2008. Análise química em órgãos de reserva de algumas herbáceas e arbóreas ocorrentes na flora do Espírito Santo, Brasil. Acta Botanica Brasilica 22(4): 1057-1067.

Cogliatti-Carvalho, L.; Nunes de Freitas, A.F.; Duarte da Rocha, C.F. \& Van Sluys, M. 2001. Variação na estrutura e na composição de Bromeliaceae em cinco zonas de restinga no Parque Nacional da Restinga de Jurubatiba, Macaé, RJ. Revista Brasileira de Botânica 24(1): 1-9.

Cordeiro, S.Z. 2005. Composição e distribuição da vegetação herbácea em três áreas com fisionomias distintas na Praia do Peró, Cabo Frio, RJ, Brasil. Acta Botanica Brasilica 19(4): 679-693.

Costa, P.H.A.; Silva, J.V.; Bezerra, M.A.; Filho, J.E.F.; Prisco, J.T. \& Filho, E.G. 2003. Crescimento e níveis de solutos orgânicos e inorgânicos em cultivares de Vigna unguiculata submetidos à salinidade. Revista Brasileira de Botânica 26(3): 289-297.

Cuzzuol, G.R.F. \& Campos, A. 2001. Aspectos nutricionais na vegetação de manguezal do estuário do rio Mucuri, Bahia, Brasil. Revista Brasileira de Botânica 24(2): 227-234.

Cuzzuol, G.R.F.; Zaidan, L.B.P. \& Carvalho, M.A.M. 2005a. Growth, photosynthate partitioning and fructan accumulation in plants of Vernonia herbacea (Vell.) Rusby under two nitrogen levels. Brazilian Journal of Plant Physiology 17(4): 401-410.

Cuzzuol, G.R.F.; Carvalho, M.A.M.; Zaidan, L.B.P. \& Furlani, P.R. 2005b. Soluções nutritivas para cultivo e produção de frutanos em plantas de Vernonia herbacea. Pesquisa Agropecuária Brasileira 40(9): 911-914.

Cuzzuol, G.R.F.; Carvalho, M.A.M. \& Zaidan, L.B.P. 2008. Fructan procution in Vernonia herbacea (Vell.) Rusby is related to adequate nitrogen supply and period of cultivation. Revista Brasileira de Botânica 31(1): 95-103. 
Emery, N.C.; Ewanchuk, P.J. \& Bertness, M.D. 2001. Competition and saltmarsh plant zonation: stress tolerators may be dominant competitors. Ecology 82(9): 2471-2485.

Evans, G.C. 1972. The Quantitative Analyses of Plant Growth. Oxford, Blackwell Scientific Publications.

Fitter, A. 1997. Nutrient Acquisition. Pp.51-72. In: Crawley, M.J. (ed.). Plant Ecology. Oxford, Blackwell Science.

Flowers, T.J.; Troke, P.F.; Yeo, A.R. 1977. The mechanism of salt tolerance in halophytes. Annual Review of Plant Physiology 28: 89-121.

Garg, N. \& Singla, R. 2004. Growth, photosynthesis, nodule nitrogen and carbon fixation in the chickpea cultivars under salt stress. Brazilian Journal of Plant Physiology 16(3): 137-146.

Griffiths, M.E. 2006. Salt spray and edaphic factors maintain dwarf stature and community composition in coastal sandplain heathlands. Plant Ecology 186: 69-86.

Hoagland, D.R. \& Arnon, D.I. 1938. The water-culture method for growing plants without soil. Circ. No. 347. Berkeley, California Agricultural Experimental Station.

Hunt, R. 1982. Plant growth curves: The functional approach to plant growth analysis. Baltimore, University Park Press.

Lambers, J. \& Poorter, H. 1992. Inherent variation in growth rate between higher plants: a search for physiological causes and ecological consequences. Advances in Ecological Research 23: 187-261.

Lambers, H.; Chapin, F.S. \& Pons, T.L. 1998. Plant Physiological Ecology. New York, Springer-Verlag.

Lee, G.; Carrow, R.N. \& Duncan, R. 2004. Photosynthetic responses to salinity stress of halophytic seashore paspalum ecotypes. Plant Science 166: 1417-1425.

Levine, J.M.; Brewer, J.S. \& Bertness, M.D. 1998. Nutrients, competition and plant zonation in a New England salt marsh. Journal of Ecology 86: 285-292.

Lourenço Junior, J. \& Cuzzuol, G.R.F. 2009. Caracterização de solos de duas formações da restinga de Guarapari-ES e sua influência na constituição química foliar de Passiflora mucronata Lam. (Passifloraceae) e Canavalia rosea (Sw.) DC (Fabaceae). Acta Botanica Brasílica 23: 239-246.

Lu, C.; Qiu, N.; Wang, B. \& Zhang, J. 2003. Salinity treatment shows no effects on photosystem II photochemistry, but increases the resistance of photosystem II to heat stress in halophyte Suaeda salsa. Journal of Experimental Botany 54(383): 851-860.

Lucas, N.M. C. \& Arrigoni, M.F. 1992. Germinação de sementes de Canavalia rosea (Sw) DC. Fabaceae. Revista Brasileira de Botânica 15(2): 105-112.

Marschner, H.; Kirkby, E.A. \& Cakmak, I. 1996. Effect of mineral nutritional statuson shoot- root partitioning of photoassimilates and cycling of mineral nutrients. Journal of Experimental Botany 47: 1255-1263.

Marschner, H. 1999. Mineral nutrition of higher plants. London, Academic Press.

Melo, F.P.L.; Neto, A.V.A.; Simabukuro, E.K. \& Tabarelli, M. 2004. Recrutamento e estabelecimento de plântulas. Pp. 237-250. In: Ferreira, A.G. \& Borghetti, F. (Orgs.). Germinação: do básico ao aplicado. Artmed, Porto Alegre.
Menezes, L.F.T. \& Araujo, D.S.D. 2000. Variação da biomassa aérea de Allagoptera arenaria (Gomes) O. Kuntze (Arecaceae) em uma comunidade arbustiva de Palmae na restinga de Marambaia, RJ. Revista Brasileira de Biologia 60(1): 147-157.

Nóbrega, R.S.A.; Motta, J.S.; Lacerda, A.M. \& Moreira, F.M.S. 2004. Tolerância de bactérias diazotróficas simbióticas à salinidade in vitro. Ciência Agrotecnológica 28(4): 899-905.

Parida, A.K.; Das, A.B. \& Mittra, B. 2003. Effects of $\mathrm{NaCl}$ stress on the structure, pigment complex composition, and photosynthetic activity of mangrove Bruguiera parviflora cloroplasts. Photosynthetica 41(2): 191-2003.

Pereira, O.J. 1990. Caracterização Fitofisionômica da Restinga de Setiba, Guarapari, ES. Pp. 207-220. In: II Simpósio de Ecossistemas da Costa Sul e Sudeste Brasileira: Estrutura, Função e Manejo. São Paulo, ACIESP

Pires, L.A.; Britez, R.M.; Martel, G. \& Pagano, S.N. 2006. Produção, acúmulo e decomposição da serapilheira em uma restinga da ilha do Mel, Paranaguá, PR, Brasil. Acta Botanica Brasilica 20: 173-184.

Poorter, H. \& Nagel, O. 2000. The role of biomass allocation in the growth response of plants to different levels of light, $\mathrm{CO}_{2}$, nutrients and water: aquantitative review. Australian Journal of Plant Physiology 27: 595-607.

Poorter, H.; Niinemets, Ü.; Poorter, L.; Wright, I.J. \& Villa, R. 2009. Causes and consequences of variation in leaf mass per area (LMA): a metaanalysis. New Phytologist 182: 565-588.

Rao, D.L.N.; Giller, K.E.; Yeo, A.R. \& Flowers, T.J. 2002. The effects of salinity and sodicity upon nodulation and nitrogen fixation in chickpea (Cicer arietinum). Annals of Botany 89: 563-570.

Rincon, E. \& Huante, P. 1994. Influence of mineral nutrient availability on growth of tree seedlings from the tropical deciduous forest. Trees, Structure and Function 9(2): 93-97.

Silva, F.A.S. \& Azevedo, C.A.V. 2007. A new version of the AssistatStatistical Assistance Software. Pp. 393-396. In: World Congress on Computer in Agriculture 4. Orlando.

Soares, F.A.L.; Gheyi, H.R.; Viana, S.B.A.; Uueda, A. \& Fernandes, P.D. 2002. Water salinity and initial development of yellow passion fruit. Scientia Agrícola 59(3): 491-497.

Suguio, K. \& Martin, L. 1990. Geomorfologia das restingas. Pp. 185-205. In: $2^{\circ}$ Simposio de ecossistema da costa sul e sudeste brasileira: estrutura, função e manejo. Águas de Lindóia, ACIESP.

Thomaz, L.D. \& Monteiro, R. 1993. Distribuição das espécies na comunidade halófila-psamófila ao longo do litoral do Estado do Espírito Santo. Arquivos de Biologia e Tecnologia 36(2): 375-399.

Valverde, T.; Pisanty, I. \& Rincón, E. 1997. Growth response of six tropical dune plant species to different nutrient regimes. Journal of Coastal Research 13(2): 497-505.

Weng-Ming, C.; Tsong-Ming, L.; Chun-Chieh, L. \& Chiu-Ping, C. 2000. Characterization of halotolerant rhizobia isolated from root nodules of Canavalia rosea from seaside areas. FEMS Microbiology Ecology 34(1): 9-16. 